\title{
Antioxidant activity of soybean peptides on human hepatic HepG2 cells
}

\author{
Carmen Lammi*, Carlotta Bollati and Anna Arnoldi
}

Department of Pharmaceutical Sciences, University of Milan, 20133 Milan, Italy

${ }^{*}$ Corresponding author: Carmen Lammi, Department of Pharmaceutical Sciences, University of Milan, via Mangiagalli 25, 20133 Milan, Italy. Tel: +39 02-50319372; E-mail: carmen.lammi@unimi.it

DOI: $10.31665 /$ JFB. 2019.7197

Received: September 28, 2019; Revised received \& accepted: September 28, 2019

Abbreviations: CVD, Cardiovascular disease; DPP-IV, dipeptidyl peptidase-IV; DPPH, 1,1-Diphenyl-2-picrylhydrazyl radical; HMGCoAR, 3-hydroxy-3-methylglutaryl coenzyme A reductase; LDL, low-density lipoprotein; LDLR, low-density lipoprotein receptor; NO, nitric oxide; RNS, reactive nitrogen species; ROS, reactive oxygen species

Citation: Lammi, C., Bollati, C., and Arnoldi, A. (2019). Antioxidant activity of soybean peptides on human hepatic HepG2 cells. J. Food Bioact. 7: 43-47.

\begin{abstract}
Soybean is an interesting source of bioactive peptides useful for the development of functional foods and nutraceuticals. In this study, the antioxidant activity of peptic (P) and tryptic (T) soybean hydrolysates was characterized. Results suggest that both hydrolysates are able to scavenge DPPH radical. Moreover, after induction of oxidative stress by using $\mathrm{H}_{2} \mathrm{O}_{2}$, either Soybean $\mathrm{P}$ or T pre-treatment reduces the ROS, lipid peroxidation, and NO levels in human hepatic HepG2 cells. $\mathrm{HepG} 2$ cells, exposed to $\mathrm{H}_{2} \mathrm{O}_{2}$ alone, produce a significant augmentation of intracellular reactive oxygen species (ROS) levels by $29.5 \%$, with the consequence of an augmentation of cellular lipid peroxidation levels up to $112.4 \pm 0.5 \%$. The pre-treatment with soybean hydrolysates restores the basal level of ROS and induces a reduction of cellular lipid peroxidation. The antioxidant ability of Soybean $\mathrm{P}$ and $\mathrm{T}$ are also confirmed by their ability to reduce the $\mathrm{H}_{2} \mathrm{O}_{2}$-induced NO levels in $\mathrm{HepG} 2$ cells.
\end{abstract}

Keywords: Antioxidant; Bioactive peptides; Food bioactive peptide; Hydrolysates; Ros; Soybean.

\section{Introduction}

Cardiovascular disease (CVD) is a leading cause of death worldwide. Many risk factors are responsible for the development of this multifactorial disease, with a prevalence of those related to atherosclerosis, which is strictly connected with oxidative stress and inflammatory processes (Wu, Xia, Kalionis, Wan, \& Sun, 2014).

Although reactive oxygen species (ROS) are produced by living organisms as a result of normal cellular metabolism, at high concentrations they produce adverse effects on cell components, such as lipids, proteins, and DNA. Oxidative stress, which refers to the shift in balance between oxidants/antioxidants in favour of oxidants, contributes to many pathological conditions (Dhalla, Temsah, \& Netticadan, 2000). Aerobic organisms have integrated antioxidant systems, which include enzymatic and nonenzymatic antioxidants, that are usually effective in blocking harmful effects of ROS. However, in pathological conditions, the antioxidant systems can be destroyed and the use of food-derived antioxidant agents could be a good strategy to impair the progression of disease related to oxidative stress (Lorenzo et al., 2018). For instance, egg, milk, meat, and fish have been identified as a good sources of peptides with interesting antioxidant activity (Ibrahim, Isono, \& Miyata, 2018; R. Liu, Xing, Fu, Zhou, \& Zhang, 2016; Nazeer, Kumar, \& Jai Ganesh, 2012; Zambrowicz et al., 2015).

Digestion or suitable technological treatments can deliver from food proteins bioactive peptides, some of which showing a multifunctional behaviour (Lammi, Aiello, Boschin, \& Arnoldi, 2019). In particular, some anti-diabetic, hypotensive, and hypocholesterolemic peptides display also antioxidant activity (Girgih et al., 2014; Iqbal \& Hussain, 2009; Siow \& Gan, 2013; Zambrowicz et al., 2015).

Numerous clinical studies have associated soy food consump- 
tion with a reduced risk of developing some chronic diseases, such as obesity, hypercholesterolemia, and insulin-resistance/type II diabetes (Velasquez \& Bhathena, 2007). As for the active substance in soy foods, the protein plays a role in cholesterol reduction (Fukui et al., 2002; Liu et al., 2014) and some hypocholesterolemic and anti-diabetic peptides have been already identified in the sequences of glycinin and $\beta$-conglycinin (Lammi, Zanoni, \& Arnoldi, 2015a; Lammi, Zanoni, \& Arnoldi, 2015b). Soybean represents thus a promising source of protein hydrolysates with a multifunctional behaviour that has been recently investigated. In particular, it has been demonstrated that peptic $(\mathrm{P})$ and tryptic $(\mathrm{T})$ hydrolysates from soybean protein show an in vitro hypocholesterolemic activity targeting 3-hydroxy-3-methylglutaryl coenzyme A reductase (HMGCoAR). Through the inhibition of this enzyme, both hydrolysates lead to an augmentation of the low-density lipoprotein (LDL) receptor (LDLR) protein levels producing an increased ability of hepatic HepG2 cells to clear LDL from the extracellular space(Lammi, Arnoldi, \& Aiello, 2019). Moreover, the same hydrolysates are able of inhibiting dipeptidyl peptidaseIV (DPP-IV) in vitro on the human recombinant enzyme as well as in human intestinal Caco-2 cells expressing DPP-IV, suggesting a potential anti-diabetic effect.

Considering that both diabetes and hypercholesterolemia are correlated to oxidative stress, this study was aimed at characterizing the antioxidant properties of the same soybean hydrolysates. This was done, initially, by evaluating in vitro the antioxidant activity employing the 1,1-diphenyl-2-picrylhydrazyl radical (DPPH) reagent, then by pre-treating HepG2 cells with the hydrolysates after the induction of oxidative stress using $\mathrm{H}_{2} \mathrm{O}_{2}$ and assessing their ability to reduce the ROS, lipid peroxidation, and nitric oxide (NO).

\section{Material and methods}

\subsection{Materials and cell cultures}

All chemicals and reagents were of analytical grade. DPPH, ROS, lipid peroxidation and Nitrite/Nitrate assays were from SigmaAldrich (St. Louis, MO, USA). The HepG2 cell line was bought from ATCC (HB-8065, ATCC from LGC Standards, Milan, Italy) and was cultured following the conditions previously described (Lammi et al., 2015b).

\subsection{Production of Soybean $P$ and $T$ hydrolysates}

Soybean P and Soybean T hydrolysates were obtained by extracting the proteins from $2 \mathrm{~g}$ of defatted soybean flour and by hydrolysing them with pepsin or trypsin. Their production and analysis of these materials are described elsewhere (Lammi et al., 2019).

\subsection{DPPH assay}

The DPPH assay to determine the antioxidant activity in vitro was performed by a standard method with slight modifications. The DPPH solution $(0.0125 \mathrm{mM}$ in methanol, $45 \mu \mathrm{L})$ was added to $15 \mu \mathrm{L}$ of the Soybean $\mathrm{P}$ and Soybean T hydrolysates at different concentrations $(0.5-5.0 \mathrm{mg} / \mathrm{mL})$. The reaction for scavenging DPPH radicals was performed in the dark at room temperature and the absorbance was measured at $520 \mathrm{~nm}$ after $30 \mathrm{~min}$ incubation.

\subsection{Cell culture}

HepG2 cell line was bought from ATCC (HB-8065, ATCC from LGC Standards, Milan, Italy) and was cultured following the conditions previously described (Lammi et al., 2015b).

\subsection{Nitrite/nitrate assay}

A total of $3 \times 10^{4} \mathrm{HepG} 2$ cells/well were seeded on a 96-well plate. The next day, cells were treated with Soybean P and Soybean $\mathrm{T}$ at different concentrations $(0.5$ and $1.0 \mathrm{mg} / \mathrm{mL})$ overnight and then $0.5 \mathrm{mM} \mathrm{H}_{2} \mathrm{O}_{2}$ was added in each well for $30 \mathrm{~min}$ at 37 ${ }^{\circ} \mathrm{C}$. After incubation, cells were centrifuged at $1,000 \mathrm{~g}$ for $15 \mathrm{~min}$ to remove insoluble material. The supernatant was transferred in a 96-well plate, then $10 \mu \mathrm{L}$ of nitrate reductase solution and 10 $\mu \mathrm{L}$ of the enzyme co-factors solution were added to the samples and the plate was incubated at $25^{\circ} \mathrm{C}$ for $2 \mathrm{~h}$. Afterward, $50 \mu \mathrm{L}$ of Griess Reagent A was added to each well and, after 5 min, 50 $\mu \mathrm{L}$ of Griess Reagent B was added for $10 \mathrm{~min}$. For the detection step, the absorbance at $540 \mathrm{~nm}$ was measured using a Synergy H1 microplate reader.

\subsection{Fluorometric intracellular ROS assay}

For cells preparation, $3 \times 10^{4} \mathrm{HepG} 2$ cells/well were seeded on a 96-well plate overnight in growth medium. The day after, the medium was removed, $50 \mu \mathrm{L} /$ well of Master Reaction Mix was added and the cells were incubated at $5 \% \mathrm{CO}_{2}, 37{ }^{\circ} \mathrm{C}$ for $1 \mathrm{~h}$ in the dark. Then, cells were treated with $5 \mu \mathrm{L}$ of $12 \times$ Soybean $\mathrm{P}$ and Soybean $\mathrm{T}$ to reach the final concentrations of $0.5 \mathrm{mg} / \mathrm{mL}$ and $1.0 \mathrm{mg} / \mathrm{mL}$ and incubated at $37^{\circ} \mathrm{C}$ for $1 \mathrm{~h}$ in the dark. To induce ROS, cells were treated with $\mathrm{H}_{2} \mathrm{O}_{2}$ at a final concentration of 0.5 $\mathrm{mM}$ for $30 \mathrm{~min}$ a $37^{\circ} \mathrm{C}$ in the dark and fluorescence signals (ex./ em. 490/525 nm) were recorded using a Synergy H1 microplate reader.

\subsection{Lipid peroxidation (MDA) assay}

HepG 2 cells $\left(5 \times 10^{5}\right.$ cells/well $)$ were seeded in a 6 well plate and, the following day, they were treated with $0.5-1.0 \mathrm{mg} / \mathrm{mL}$ of Soybean $\mathrm{P}$ and $\mathrm{T}$ for $24 \mathrm{~h}$ at $37{ }^{\circ} \mathrm{C}$ under $5 \% \mathrm{CO}_{2}$ atmosphere. The day after, cells were incubated with $\mathrm{H}_{2} \mathrm{O}_{2} 1 \mathrm{mM}$ or vehicle $\left(\mathrm{H}_{2} 0\right)$ for $30 \mathrm{~min}$, than collected and homogenized in $300 \mu \mathrm{L}$ ice-cold MDA lysis buffer containing $3 \mu \mathrm{L}$ of BHT $(100 \times)$. Samples were centrifuged at $13,000 \times \mathrm{g}$ for $10 \mathrm{~min}$, then they were filtered through a $0.2 \mu \mathrm{m}$ filter to remove insoluble material. To form the MDA-TBA adduct, $300 \mu \mathrm{L}$ of the TBA solution were added into each vial containing samples and incubated at $95{ }^{\circ} \mathrm{C}$ for $60 \mathrm{~min}$, then cooled to RT for $10 \mathrm{~min}$ in an ice bath. For analysis, $100 \mu \mathrm{L}$ of each reaction mixture were pipetted into a 96 well plate and the absorbance was measured at $532 \mathrm{~nm}$ using the Synergy H1 fluorescent plate reader from Biotek. To normalize the data, total proteins for each sample were quantified by Bradford method.

\subsection{Statistically analysis}

Statistical analyses were carried out by One-way ANOVA (Graphpad Prism 8) followed by Brown-Forsythe's test. Values were expressed as means $\pm \mathrm{sd}$; P-values $<0.05$ were considered to be significant. 

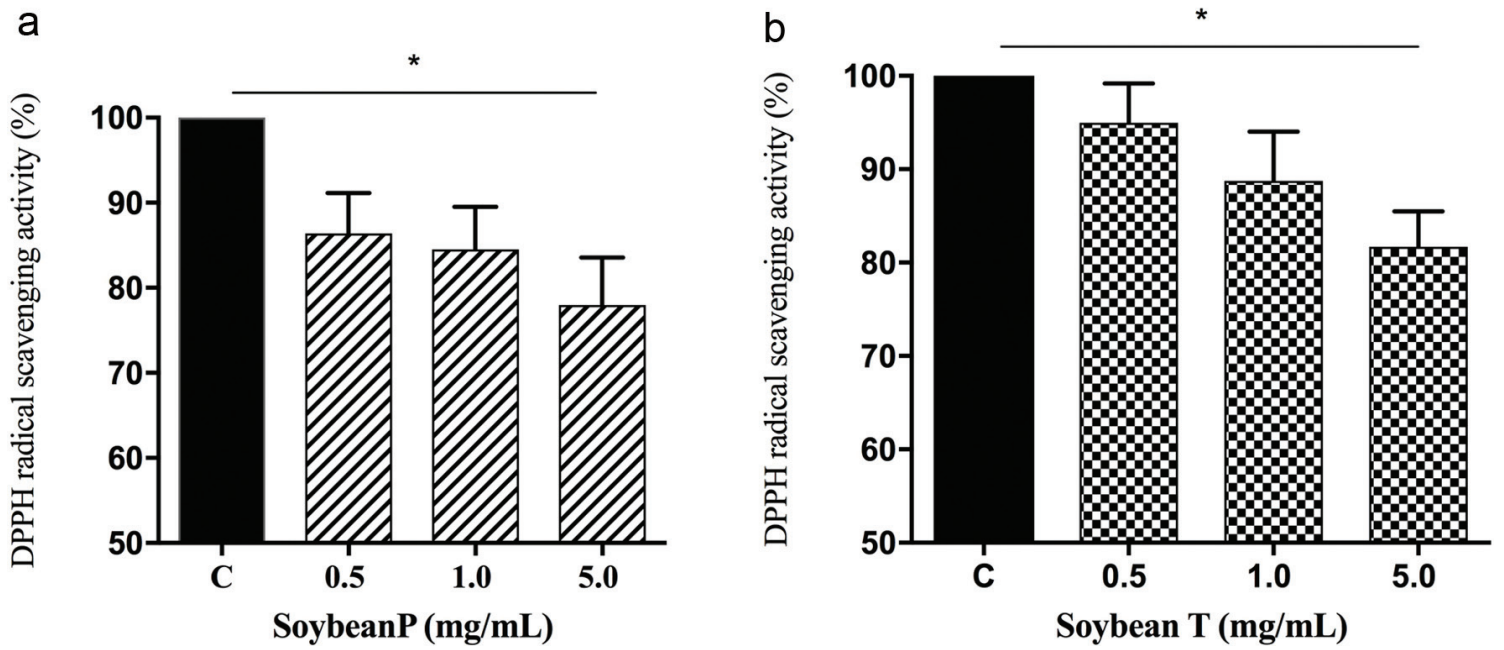

Figure 1. In vitro evaluation of the DPPH radical scavenger activity of Soybean $\mathbf{P}$ (a) and Soybean $\mathbf{T}$ (b) hydrolysates. The data points represent the averages \pm sd of four independent experiments in duplicate. $\left({ }^{*}\right) p<0.05$. C: control sample.

\section{Results and discussion}

\subsection{In vitro radical scavenging activity of Soybean $P$ and $T$ hy- drolysates}

In order to evaluate the in vitro radical scavenging activity of Soybean P and T hydrolysates, the DPPH assay was employed. The hydrolysates were tested in the range from 0.5 to $5.0 \mathrm{mg} / \mathrm{mL}$. The results clearly suggested that both hydrolysates have a modest ability to scavenge DPPH radical (Figure $1 \mathrm{a}-\mathrm{b}$ ). Soybean P reduces the DPPH radicals by $13.7 \%, 15.5$, and $22.1 \%$ at $0.5,1.0$, and 5.0 $\mathrm{mg} / \mathrm{mL}$, respectively (Figure 1a), whereas Soybean T diminishes the DPPH radicals by $5.1 \%, 11.3 \%$, and $18.4 \%$, respectively (Figure $1 \mathrm{~b}$ ), indicating that the former hydrolysate has a better radical scavenging activity than the latter. This different behaviour may be explained considering the different physiochemical properties of these hydrolysates. Thus, Soybean P is predominantly characterized by peptides ranging from 1 to $1.2 \mathrm{kDa}$, whereas Soybean $\mathrm{T}$ contains mostly large amounts of medium and long peptides with a molecular weight larger than $2 \mathrm{kDa}$. Moreover, the average hydrophobicity of pepsin peptides is larger than that of trypsin peptides (Lammi et al., 2019). Instead, Soybean P contains 22.2\% peptides with lengths ranging from 8 to 10 amino acid residues and an average hydrophobicity of $48.1 \mathrm{kcal} \mathrm{mol}^{-1}, 73.6 \%$ peptides with a length of 11-20 amino acid residues and an average hydrophobicity of $44.5 \mathrm{kcal} \mathrm{mol}^{-1}$, and $4.2 \%$ of peptides with a length of $20-21$ amino acids and an average hydrophobicity of $50.7 \mathrm{kcal} \mathrm{mol}^{-1}$. On the contrary, Soybean T contains $6.2 \%$ peptides with a length of 9-10 amino acid residues and an average hydrophobicity of 32.2 $\mathrm{kcal} \mathrm{mol}{ }^{-1}, 67.2 \%$ peptides with a length of 11-20 amino acid residues and an average hydrophobicity of $39.2 \mathrm{kcal} \mathrm{mol}^{-1}$, and $26.6 \%$ peptides with a length of 20-27 amino acids and an average hydrophobicity of $40.4 \mathrm{kcal} \mathrm{mol}^{-1}$.

Even though, the radical scavenging activity of food protein hydrolysates is influenced by many factors (i.e. the proteases used for the generation of the hydrolysates, size and amino acid composition of the peptides, and the DPPH assay conditions), our findings are in line with previous studies (Aluko \& Monu, 2003; Li, Jiang, Zhang, Mu, \& Liu, 2008; Udenigwe, Lu, Han, Hou, \& Aluko, 2009). In particular, soybean $P$ and T hydrolysates resulted to be more active that a hempseed protein hydrolysate, obtained by co-digesting the proteins with pepsin and pancreatin, which has shown a poor scavenger of DPPH activity, i.e. about 4\% (Girgih, Udenigwe, \& Aluko, 2011). Instead, rice bran protein hydrolysates, obtained after the hydrolysis of the proteins with Alcalase, displayed a DPPH free radical scavenging activity of about $32 \%$ at $20 \mathrm{mg} / \mathrm{mL}$ (Wattanasiritham, 2015). Finally, fish and chicken bones hydrolysates, obtained using trypsin, have shown an antioxidant activity of about $15 \%$ and $10 \%$, respectively, at $5.0 \mathrm{mg} / \mathrm{mL}$ (Centenaro, Mellado, \& Prentice-Hernandez, 2011).

\subsection{Soybean $P$ and $T$ hydrolysates modulate the $\mathrm{H}_{2} \mathrm{O}_{2}$-induced oxidative stress in human hepatic HepG2 cells}

Excessive production of intracellular ROS leads to severe cellular damage, which may affect proteins, DNA and lipid stability. (Dhalla et al., 2000) For this reason, in order to evaluate whether Soybean $\mathrm{P}$ and $\mathrm{T}$ hydrolysates modulate the $\mathrm{H}_{2} \mathrm{O}_{2}$-induced $\mathrm{ROS}$ production, HepG2 cells were pre-treated with both hydrolysates $(0.5$ and $1.0 \mathrm{mg} / \mathrm{mL}) \mathrm{O} / \mathrm{N}$ at $37^{\circ} \mathrm{C}$. The following day, the same cells were treated with $0.5 \mathrm{mM} \mathrm{H}_{2} \mathrm{O}_{2}$ for $30 \mathrm{~min}$ at $37^{\circ} \mathrm{C}$. Results (Figure 2) clearly highlight that HepG2 cells, exposed to $\mathrm{H}_{2} \mathrm{O}_{2}$ alone, produce a significant augmentation of intracellular ROS levels by $29.5 \% v s$ control cells $(\mathrm{p}<0.01)$, which was attenuated by the pre-treatment with Soybean $\mathrm{P}$ and $\mathrm{T}$ hydrolysates: Soybean $\mathrm{P}$ reduced the $\mathrm{H}_{2} \mathrm{O}_{2}$-induced intracellular ROS by $19.5 \%$ and $14.2 \%$ at 0.5 and $1.0 \mathrm{mg} / \mathrm{mL}$, respectively, whereas Soybean T by $17.3 \%$ and $13.3 \%$ at 0.5 and $1.0 \mathrm{mg} / \mathrm{mL}$, respectively $(\mathrm{p}<0.05)$. These findings underline a dramatic increase of intracellular ROS, but the pre-treatment with Soybean P and T hydrolysates significantly protects the HepG2 cells restoring the ROS level to basal condition and confirming their good ability to act as natural antioxidant. As already underlined, high oxidative stress results in significant damage to human cells by altering proteins, lipids and DNA, leading to several simultaneous processes, which may culminate in pathological conditions involved in CVD progression.

Lipid of cellular membranes are susceptible to an oxidative attack, typically by ROS, resulting in a well-defined chain reaction with the production of end products such as malondialdehyde (MDA). Based on these considerations, the capacity of Soybean P 


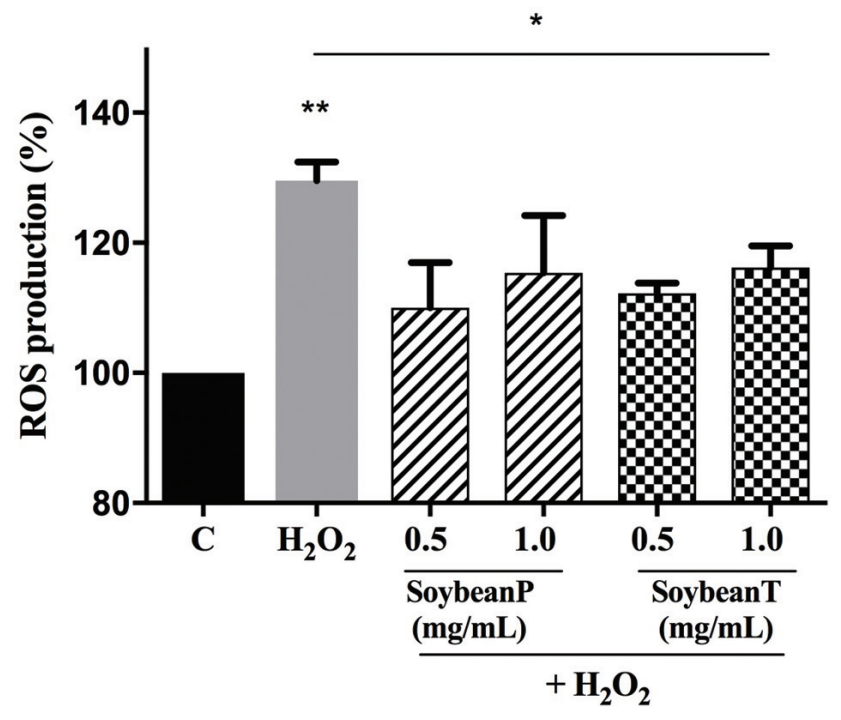

Figure 2. Evaluation of the effects of Soybean $P$ and T hydrolysates on the $\mathrm{H}_{2} \mathrm{O}_{2}$-induced ROS production levels at human hepatic HepG2 cells. The data points represent the averages $\pm \mathrm{sd}$ of six independent experiments in duplicate. $\left({ }^{*}\right) \mathrm{p}<0.05,\left({ }^{* *}\right) \mathrm{p}<0.01$. C: control cells.

and $\mathrm{T}$ hydrolysates to modulate the $\mathrm{H}_{2} \mathrm{O}_{2}$-induced lipid peroxidation in human hepatic HepG2 cells was assessed measuring the reaction of MDA with thiobarbituric acid (TBA) to form fluorometric $(\lambda \mathrm{ex}=532 / \lambda \mathrm{em}=553 \mathrm{~nm})$ product, proportional to the MDA present. Figure 2 clearly suggests that, in agreement with the observed increase of ROS after the $\mathrm{H}_{2} \mathrm{O}_{2}$ treatment, a significant increase of the lipid peroxidation at cellular level up to $112.4 \pm$

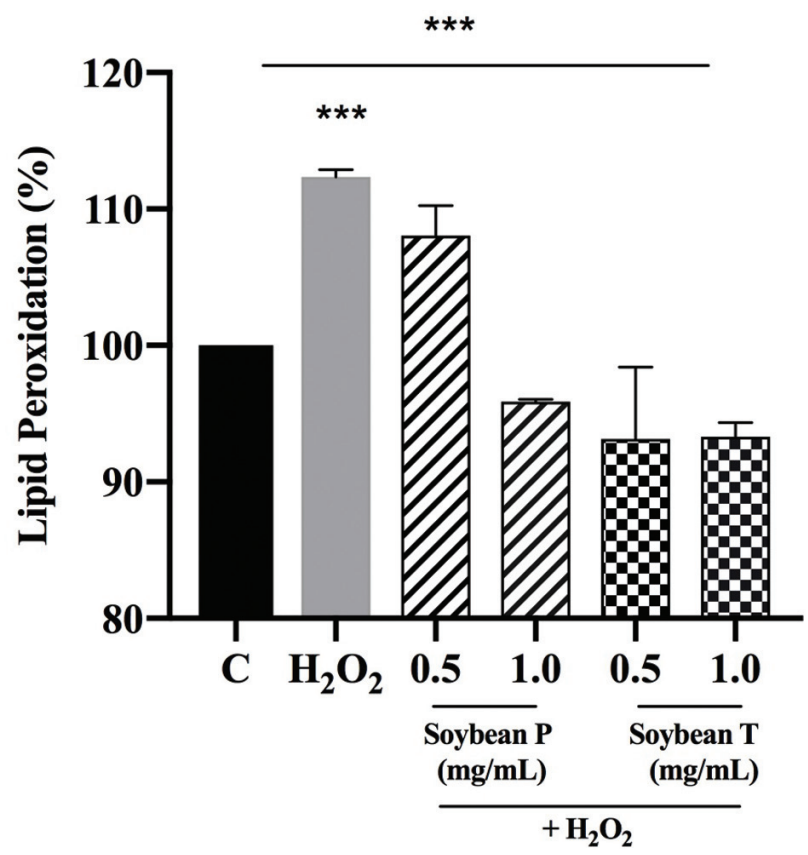

Figure 3. Evaluation of the effects of Soybean $P$ and T hydrolysates on the $\mathrm{H}_{2} \mathrm{O}_{2}$-induced lipid peroxidation levels at human hepatic HepG2 cells. The data points represent the averages \pm sd of six independent experiments in duplicate. $\left({ }^{* * *}\right) \mathrm{p}<0.001$. C: control cells.

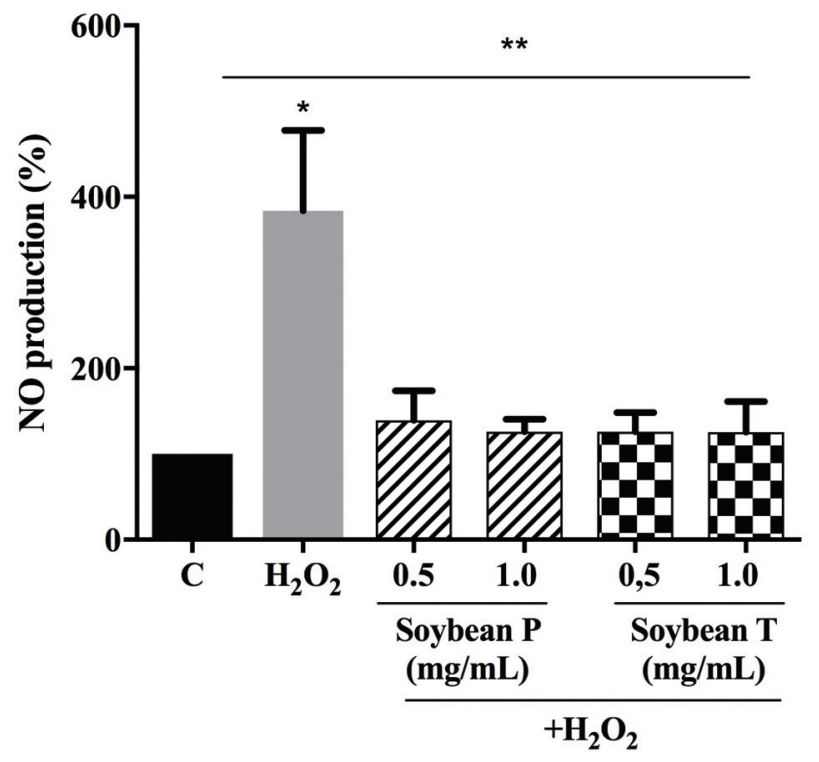

Figure 4. Investigation of the ability of Soybean $\mathrm{P}$ and $\mathrm{T}$ hydrolysates to modulate the $\mathrm{H}_{2} \mathrm{O}_{2}$-induced $\mathrm{NO}$ level production at human hepatic HepG2 cells. The data points represent the averages \pm sd of six independent experiments in duplicate. $\left({ }^{*}\right) p<0.05,\left({ }^{* *}\right) p<0.01$. C: control cells.

$0.5 \%$ was observed $(\mathrm{p}<0.001)$. In addition, the pre-treatment of HepG2 cells with both Soybean $\mathrm{P}$ and $\mathrm{T}$ hydrolysates determine a significant reduction of lipid peroxidation even under basal conditions $(\mathrm{p}<0.01)$. As illustrated in the Figure 3, Soybean P decreases the lipid peroxidation up to $108.1 \pm 2.2 \%$ and $95.8 \pm 0.2 \%$ at 0.5 and $1.0 \mathrm{mg} / \mathrm{mL}$, respectively, whereas Soybean T up to 93.1 $\pm 5.3 \%$ and $93.3 \pm 1.0 \%$ at 0.5 and $1.0 \mathrm{mg} / \mathrm{mL}$, respectively. Since the lipid peroxidation is a validated marker of oxidative stress, these findings confirm the good antioxidant property of soybean hydrolysates and that the tryptic hydrolysate is more active than the peptic one.

\subsection{Soybean $P$ and $T$ hydrolysates modulate the $\mathrm{H}_{2} \mathrm{O}_{2}$-induced NO production in human hepatic HepG2 cells}

The ROS act either as a signalling molecule or a mediator of inflammation (Mittal, Siddiqui, Tran, Reddy, \& Malik, 2014). Superoxide can rapidly combine with NO to form reactive nitrogen species (RNS), such as peroxynitrite, with a reaction rate that is faster than the dismutation of superoxide by superoxide dismutase (Beckman, 1996). In addition, the RNS lead to a nitrosative stress, which parallels the pro-inflammatory activity of ROS (Sunil, Shen, Patel-Vayas, Gow, Laskin, \& Laskin, 2012). More and more emerging evidences clearly underline the intricate relation between oxidative stress and inflammation (Mittal et al., 2014).

Based on these considerations, the Soybean $\mathrm{P}$ and $\mathrm{T}$ hydrolysates effects on the $\mathrm{NO}$ level production were evaluated at human hepatic $\mathrm{HepG} 2$ cells, after oxidative stress induction. $\mathrm{A}_{2} \mathrm{O}_{2}$ treatment was used to induce the oxidative stress and the NO levels, produced at intracellular levels, were measured. Figure 4 clearly indicates that the $\mathrm{H}_{2} \mathrm{O}_{2}$ treatment dramatic increases the NO levels up to $383.6 \pm 94.1 \%(\mathrm{p}<0.05)$ and that the pre-treatment with soybean peptides reduces the $\mathrm{H}_{2} \mathrm{O}_{2}$-induced $\mathrm{NO}$ levels leading their values closer to the basal levels $(\mathrm{p}<0.01)$. In particular, Soybean $\mathrm{P}$ $(0.5$ and $1.0 \mathrm{mg} / \mathrm{mL})$ decreases the NO level up to $139.1 \pm 34.7 \%$ 
and $125.9 \pm 14.7 \%$, whereas Soybean T $(0.5$ and $1.0 \mathrm{mg} / \mathrm{mL})$ up to $125.8 \pm 22.6 \%$ and $125.6 \pm 35.8 \%$, respectively. Interestingly, these findings confirm the same trend that was observed assessing the effect of soybean peptides on the modulation of $\mathrm{H}_{2} \mathrm{O}_{2}$-induced cellular lipid peroxidation. In particular, Soybean $\mathrm{T}$ hydrolysate seems to be also in this case slightly more active to restore the basal intracellular NO levels.

\section{Conclusion}

Soybean is an interesting source of bioactive peptides useful for the development of functional foods and nutraceuticals. Many evidences clearly suggest that soybean peptides mediate hypocholesterolemic, hypotensive and hypoglycaemic activities which are strictly related to oxidative stress. Our results indicate that soybean peptides could also contribute to an antioxidant activity which is linked to the modulation of intracellular ROS and NO levels leading to a reduction of lipid degradation.

\section{Acknowledgments}

We acknowledge Carlo Sirtori Foundation (Milan, Italy) for having provided part of equipment used in this experimentation and the Fondazione Cariplo, project "SUPER-HEMP: Sustainable Process for Enhanced Recovery of Hempseed Oil" number: 2017 1005. Moreover, we thank the project "DISCOVERY - Disaggregation of conventional vegetable press cakes by novel techniques to receive new products and to increase the yield", bando ERANET SUSFOOD2

\section{Author contributions}

Experiment ideation and design, CL.; Biological experiments, C.L. C.B. Data analysis, C.L. and C.B.; Discussion of the results, C.L., Manuscript writing, C.L. and A.A

\section{Conflict of interest}

The authors declare they have no conflicts of interest.

\section{References}

Aluko, R.E., and Monu, E. (2003). Functional and bioactive properties of quinoa seed protein hydrolysates. J Food Sci 68(4): 1254-1258.

Beckman, J.S. (1996). Oxidative damage and tyrosine nitration from peroxynitrite. Chem Res Toxicol 9(5): 836-844.

Centenaro, G.S., Mellado, F.S., and Prentice-Hernandez, C. (2011). Antioxidant activity of protein hydrolysates of fish and chicken bones. Adv J Food Sci Technol. 3: 280-288.

Dhalla, N.S., Temsah, R.M., and Netticadan, T. (2000). Role of oxidative stress in cardiovascular diseases. J Hypertens 18(6): 655-673.

Fukui, K., Tachibana, N., Wanezaki, S., Tsuzaki, S., Takamatsu, K., Yamamoto, T., and Shimoda, T. (2002). Isoflavone-free soy protein prepared by column chromatography reduces plasma cholesterol in rats. J Agric Food Chem 50(20): 5717-5721.

Girgih, A.T., Alashi, A.M., He, R., Malomo, S.A., Raj, P., Netticadan, T., and Aluko, R.E. (2014). A novel hemp seed meal protein hydrolysate re- duces oxidative stress factors in spontaneously hypertensive rats. Nutrients 6(12): 5652-5666.

Girgih, A.T., Udenigwe, C.C., and Aluko, R.E. (2011). In vitro antioxidant properties of hemp seed (Cannabis sativa L.) protein hydrolysate fractions. J Am Oil Chem Soc 88(3): 381-389.

Ibrahim, H.R., Isono, H., and Miyata, T. (2018). Potential antioxidant bioactive peptides from camel milk proteins. Anim Nutr 4(3): 273-280.

Iqbal, J., and Hussain, M.M. (2009). Intestinal lipid absorption. Am J Physiol Endocrinol Metab 296(6): E1183-1194.

Lammi, C., Aiello, G., Boschin, G., and Arnoldi, A. (2019). Multifunctional peptides for the prevention of cardiovascular disease: A new concept in the area of bioactive food-derived peptides. J Funct Foods 55: 135-145.

Lammi, C., Arnoldi, A., and Aiello, G. (2019). Soybean Peptides Exert Multifunctional Bioactivity Modulating 3-Hydroxy-3-Methylglutaryl-CoA Reductase and Dipeptidyl Peptidase-IV Targets in Vitro. J Agric Food Chem 67(17): 4824-4830.

Lammi, C., Zanoni, C., and Arnoldi, A. (2015a). IAVPGEVA, IAVPTGVA, and LPYP, three peptides from soy glycinin, modulate cholesterol metabolism in HepG2 cells through the activation of the LDLR-SREBP2 pathway. J Funct Foods 14: 469-478.

Lammi, C., Zanoni, C., and Arnoldi, A. (2015b). Three peptides from soy glycinin modulate glucose metabolism in human hepatic HepG2 cells. Int J Mol Sci 16(11): 27362-27370.

Li, Y., Jiang, B., Zhang, T., Mu, W., and Liu, J. (2008). Antioxidant and free radical-scavenging activities of chickpea protein hydrolysate $(\mathrm{CPH})$. Food Chem 106(2): 444-450.

Liu, R., Xing, L., Fu, Q., Zhou, G.H., and Zhang, W.G. (2016). A Review of Antioxidant Peptides Derived from Meat Muscle and By-Products. Antioxidants (Basel) 5(3): 32.

Liu, Z.-M., Ho, S.C., Chen, Y.-M., Ho, S., To, K., Tomlinson, B., and Woo, J. (2014). Whole soy, but not purified daidzein, had a favorable ef fect on improvement of cardiovascular risks: A 6-month randomized, double-blind, and placebo-controlled trial in equol-producing postmenopausal women. Mol. Nutr. Food Res. 58(4): 709-717.

Lorenzo, J.M., Munekata, P.E.S., Gómez, B., Barba, F.J., and Toldrá, F. (2018). Bioactive peptides as natural antioxidants in food productsA review. Trends Food Sci Tech. 79: 136-147.

Mittal, M., Siddiqui, M.R., Tran, K., Reddy, S.P., and Malik, A.B. (2014). Reactive oxygen species in inflammation and tissue injury. Antioxid Redox Signal 20(7): 1126-1167.

Nazeer, R.A., Kumar, N.S., and Jai Ganesh, R. (2012). In vitro and in vivo studies on the antioxidant activity of fish peptide isolated from the croaker (Otolithes ruber) muscle protein hydrolysate. Peptides 35(2): 261-268.

Siow, H.L., and Gan, C.Y. (2013). Extraction of antioxidative and antihypertensive bioactive peptides from Parkia speciosa seeds. Food Chem 141(4): 3435-3442

Sunil, V.R., Shen, J., Patel-Vayas, K., Gow, A.J., Laskin, J.D., and Laskin, D.L. (2012). Role of reactive nitrogen species generated via inducible nitric oxide synthase in vesicant-induced lung injury, inflammation and altered lung functioning. Toxicol Appl Pharmacol 261(1): 22-30.

Udenigwe, C.C., Lu, Y.L., Han, C.H., Hou, W.C., and Aluko, R.E. (2009). Flaxseed protein-derived peptide fractions: Antioxidant properties and inhibition of lipopolysaccharide-induced nitric oxide production in murine macrophages. Food Chem 116(1): 277-284.

Velasquez, M.T., and Bhathena, S.J. (2007). Role of dietary soy protein in obesity. Intern J Med Sci 4(2): 72-82.

Wattanasiritham, L.K., and S Theerakulkait, C. (2015). Antioxidant activity of rice bran protein extract, its enzymatic hydrolysates and its combination with commercial antioxidants. Pakistan J Nut. 14: 647-652.

Wu, J., Xia, S., Kalionis, B., Wan, W., and Sun, T. (2014). The role of oxidative stress and inflammation in cardiovascular aging. Biomed Res Int 2014: 615312.

Zambrowicz, A., Pokora, M., Setner, B., Dąbrowska, A., Szołtysik, M., Babij, K., and Chrzanowska, J. (2015). Multifunctional peptides derived from an egg yolk protein hydrolysate: isolation and characterization. Amino Acids 47(2): 369-380. 